\title{
The role of micro health insurance in providing financial risk protection in developing countries- a systematic review
}

\author{
Shifa Salman Habib ${ }^{1 *}$, Shagufta Perveen ${ }^{1}$ and Hussain Maqbool Ahmed Khuwaja²
}

\begin{abstract}
Background: Out of pocket payments are the predominant method of financing healthcare in many developing countries, which can result in impoverishment and financial catastrophe for those affected. In 2010, WHO estimated that approximately 100 million people are pushed below the poverty line each year by payments for healthcare. Micro health insurance $(\mathrm{MHI})$ has been used in some countries as means of risk pooling and reducing out of pocket health expenditure. A systematic review was conducted to assess the extent to which MHI has contributed to providing financial risk protection to low-income households in developing countries, and suggest how the findings can be applied in the Pakistani setting.

Methods: We conducted a systematic search for published literature using the search terms "Community based health insurance AND developing countries", "Micro health insurance AND developing countries", "Mutual health insurance AND developing countries", "mutual OR micro OR community based health insurance" "Health insurance AND impact AND poor" "Health insurance AND financial protection" and "mutual health organizations" on three databases, Pubmed, Google Scholar and Science Direct (Elsevier). Only those records that were published in the last ten years, in English language with their full texts available free of cost, were considered for inclusion in this review. Hand searching was carried out on the reference lists of the retrieved articles and webpages of international organizations like World Bank, World Health Organization and International Labour Organization.

Results: Twenty-three articles were eligible for inclusion in this systematic review (14 from Asia and 9 from Africa). Our analysis shows that $\mathrm{MHI}$, in the majority of cases, has been found to contribute to the financial protection of its beneficiaries, by reducing out of pocket health expenditure, catastrophic health expenditure, total health expenditure, household borrowings and poverty. MHI also had a positive safeguarding effect on household savings, assets and consumption patterns.
\end{abstract}

Conclusion: Our review suggests that $\mathrm{MHI}$, targeted at the low-income households and tailored to suit the cultural and geographical structures in the various areas of Pakistan, may contribute towards providing protection to the households from catastrophe and impoverishment resulting from health expenditures. This paper emphasizes the need for further research to fill the knowledge gap that exists about the impact of $\mathrm{MHI}$, using robust study designs and impact indicators.

Keywords: Mutual health insurance, Micro health insurance, Community based health insurance, Mutual health organizations, Developing countries, Financial protection, Pakistan, Systematic review

\footnotetext{
* Correspondence: shifa.hpm12006@student.aku.edu

'Department of Community Health Sciences, The Aga Khan University,

Stadium Road, 74800 Karachi, Pakistan

Full list of author information is available at the end of the article
} 


\section{Background}

Financial catastrophe and impoverishment as a result of medical expenses, especially out of pocket (OOP) expenditures, has been a concern globally, more so, in developing countries [1] where the inadequacy of state provided health system results in alarmingly excessive OOP expenditure [2]. OOP payments for health care comprise 4-5.5 \% of total household consumption in China, India, Bangladesh and Vietnam. This estimate is much lower, 1.4-2.7 \% for Malaysia, Thailand, the Philippines, Sri Lanka and Hong Kong, as these countries are more economically stable than the first four countries, that are more heavily dependent on OOP spending for healthcare [3]. Literature suggests that approximately 100 million people are pushed below the poverty line each year by payments for health care [4].

The Alma-Ata declaration of 1978 advocated "health for all", implying equitable access to health services for all individuals globally, regardless of socioeconomic class [5]. Despite this, unaffordability of healthcare is now accepted as one of the most decisive barriers to access to healthcare [6]. Substantial evidence from developing countries ascertain the continued presence of inequity in health, showing that the rich receive considerably more health benefits than the poor $[7,8]$. More so, in the event of illness, many low-income households obtain sub-optimal care or forgo medical care altogether [9-11].

In Pakistan, the majority of health care is financed through OOP payments, which accounts for $55 \%$ of the total healthcare costs [12]. Merely $26 \%$ of the population is covered partially for its healthcare costs by the government, armed forces, corporate sector or other safety nets [13]. The gross total OOP health expenditures incurred by private households in the fiscal year 2011-12 amounted to PKR 315 billion (\$ 2.9 billion) [12]. To cover the expenses associated with an event of sudden illness, the lowincome households in Pakistan, often employ coping strategies such as drawing down savings, borrowing and selling productive assets such as cattle, poultry and land [14]. These coping mechanisms are frequently inadequate to cover the healthcare costs and the consequential debt may result in impoverishment of the effected household [9].

The health insurance strategy is gaining popularity, particularly in the developing countries, as a mode of providing financial protection from the healthcare costs. There are various diverse health insurance models operational in different countries, such as the national or social health insurance, which entails mandatory enrollment by the individuals [15] or voluntary insurance models such as private health insurance or micro health insurance (MHI).
The majority of the high-income countries rely heavily on general taxation (for example, the United Kingdom) or mandated health insurance (France, Germany) for healthcare financing [16]. On the contrary, in lowincome countries, developing an efficient tax-funded health system maybe a difficult task, due to the dearth of a robust tax base and low institutional capacity to run the tax collecting apparatus efficiently [17]. Thus, in these countries, MHI may be able to provide financial protection, to a significant proportion of the population, against the downside of medical expenses. MHI is a kind of micro-insurance, which can be defined as "protection of low income people against financial risk, in exchange of payment of premiums, according to the probability and cost of the risk" $[5,18]$

Varying terminologies, such as mutual health insurance or community-based health insurance, are used in different settings to designate MHI institutions. The three main defining criteria used in this paper for identifying any insurance program as $\mathrm{MHI}$ include a target population of low-income individuals or households, voluntary participation of the enrolled individuals or households and provision of health insurance services in exchange of premiums paid by the enrollees.

This paper aims to explore the prospect of instigation of a health financing reform in Pakistan with health insurance as a potential mode of providing financial security from the cost of healthcare consumption. We conducted a systematic review to provide cumulative evidence for the extent to which MHI has been useful, as an intervention in providing financial risk protection in developing countries, particularly to low-income households.

\section{Methods}

\section{Search strategy}

To conduct this systematic review, the principal investigator $(\mathrm{SH})$ and co-investigator (SP) developed a search strategy to identify peer reviewed publications and reports of research studies and project evaluations in which $\mathrm{MHI}$, in one of its organizational settings, was delivered to low income households within developing countries. We conducted a systematic search, from November and December 2015, using combinations of text words and thesaurus terms "Community based health insurance AND developing countries", "Micro health insurance AND developing countries", "Mutual health insurance AND developing countries", "mutual OR micro OR community based health insurance" "Health insurance AND impact AND poor" "Health insurance AND financial protection" and "mutual health organizations". These search terms were entered concurrently on three databases, Pubmed, Google Scholar and Science Direct (Elsevier). From these three databases, only those 
records, that were published in the last ten years having full texts that were available free of cost, were considered for inclusion in this review. As there was no funding available for conducting this systematic review, the authors decided to exclude non-English articles (to avoid translation costs). Only the abstract was available for one of the searched articles. The institutional librarian and the authors of the respective study were approached for the provision of full text.

For Science Direct, further filters were applied to shortlist original articles, review articles and short communications for consideration, from journals pertaining to medicine and dentistry, nursing and allied and social sciences. The search was restricted to title only to limit the vast number of irrelevant articles from Google scholar, whereas for Science Direct and Pubmed, the search was limited to title and abstract. Other than peer reviewed journal articles, organizational research papers published by international bodies were also eligible for inclusion in this systematic review. Furthermore, hand searching was done on the reference list of the articles shortlisted by the above-mentioned strategy and those obtained from institutional websites such as World Bank, World Health Organization (WHO) and International Labor Organization (ILO), for relevant papers and reports. Figure 1 shows the flow of systematic search results.
The following inclusion criteria were considered for all publications and reports;

- Population: (i) the intervention, that is MHI, is delivered to low income households (ii) the study is carried out in a developing country

- Intervention: (i) micro health insurance was the only intervention considered (as defined in the preceding sections), in any of its organizational forms, which excluded health insurance of any other sort such as social health insurance or government based safety nets.

- Outcome: the considered outcome is financial protection. Studies reporting irrelevant outcomes such as (1) increased access to health care, (2) increased health care utilization, (3) improved demand for health care or (4) improved healthseeking behavior were outside the scope of this review.

\section{Data collection process}

Our search resulted in 1001 papers from the three databases. After title and abstract review of these papers, 28 articles were shortlisted for review of full text in the light of our inclusion criterion. Out of these, 17 papers were identified as being eligible to be included in this systematic review.

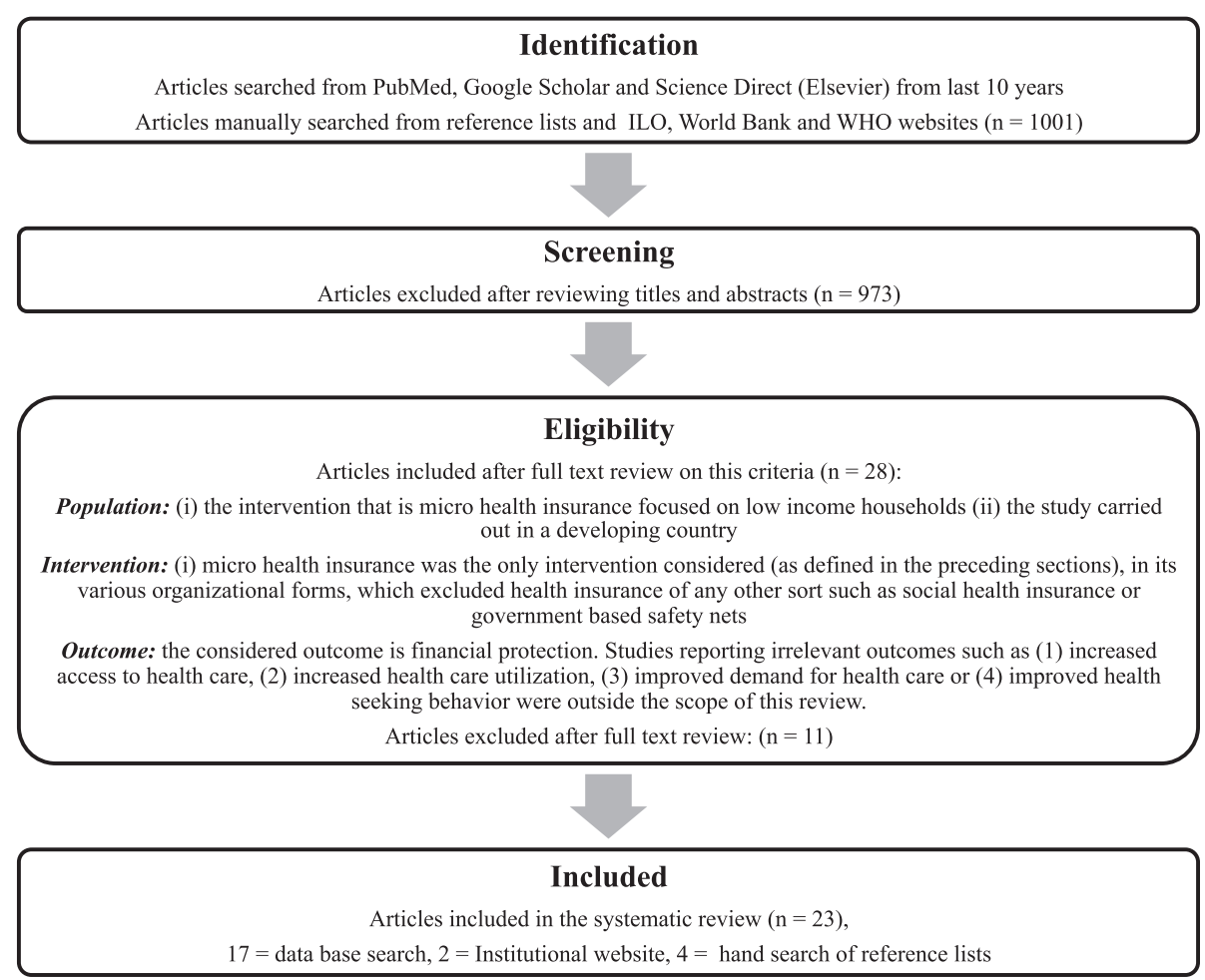

Fig. 1 Systematic flow of search results 
Furthermore, two eligible studies from ILO's website, and four from the reference lists of articles retrieved through systematic database search, were included in the final list of articles for data extraction, bringing the total number of included studies to 23. The first author independently assessed the title and abstracts and then reviewed the full texts of the shortlisted papers, in the light of the inclusion criteria, to determine whether those studies are eligible to be included in this review. Any ambiguity was resolved though discussion and consultation with the other two authors. Two authors extracted the data using a standard data extraction form (Table 1).

Data extracted from each article/report included the name of journal, publication date, WHO region and country of operation, study design, objectives of the study, data collection strategy, target population (low income households), measures of financial protection assessed and the key findings. In the final step, we assessed the adequacy and quality of information in the selected studies on the study design, sample size of the target population, sampling methods, interventions, evaluation methods and results. Finally, the information extracted from the 23 included studies was recorded in the standard data extraction form. Since the study population, organizational setting of health insurance, methodology, evaluation designs and measures of financial protection being evaluated in these studies were heterogeneous; we decided that it was not possible to conduct a meta-analysis or quantitative synthesis.

The list of excluded citations is presented in Table 2.

Table 1 Data extraction form

Title
Journal/publication body
Citation
Year of publication
Date of review
Study design/evaluation design:
Sampling technique (if given)
WHO region
Country/Area of intervention
Type of health insurance
Name of MHI or implementing body
Other components of intervention (if any)
Study population
Data collection strategy?
Objectives of the of study
Measures of financial protection evaluated
Key findings

\section{Quality assessment}

The Mirza and Jenkins checklist was used to assess the quality of the articles meeting the inclusion criteria which includes: 1) Explicit study aims stated 2) Sample size justification given 3) Sample representative of population 4) Inclusion and exclusion criteria stated 5) Reliability and validity of measures justified 6) Response rate and dropout rate specified 7) Data adequately described 8) Statistical significance assessed 9) Discussion of generalizability given10) Null findings interpreted [19]. Only one study, out of the 23, gave complete details about the methods as per the checklist used (Table 3). However, due to scarcity of the available literature, the authors decided to include all the articles in this systematic review. Furthermore, the included studies were also categorized according to the outcomes they assessed and the quality of evidence, for each outcome, was classified as being high, moderate or low, based on the average of individual quality scores of the included studies (Tables 3 and 4). The quality of evidence for each of the studied outcomes varied between moderate and high (Table 4). The evidence found for the outcomes, reduction in $\mathrm{CHE}$ and protection of household savings, were particularly noted to be high in quality.

\section{Results}

As described above, from the list of 28 articles, originally shortlisted after title/abstract review, 11 were excluded either due to lack of evidence on financial protection being directly attributed to $\mathrm{MHI}$, the health insurance scheme not meeting the definition of MHI in terms of premiums paid by the insured or in terms of voluntary participation, or the effect being evaluated in the paper being the impact on health center costs and not the enrolled households.

Table 5 provides a snapshot of the 23 articles that were finally included, summarizing name of the MHI project (or the implementing organization), study design and setting, the measure of financial protection assessed and the key findings. The quality assessment of the included articles is presented in Table 3 .

\section{A: Characteristics of the included studies Study setting and target population}

Out of the 23 studies/reports included in this review, five are from China, all reporting the financial protection provided by the New Cooperative Medical Scheme (NCMS) in China. NCMS is operated, and heavily subsidized, by the government of China and provides voluntary insurance for its poor rural population. It was initiated in 2003, and was primarily aimed at covering catastrophic health expenditures (CHE). One of these studies [20] conducted a survey of 354 counties in the Western and Central regions of China. The second [21] 
Table 2 Excluded citations with justification for exclusion

\begin{tabular}{lll}
\hline Justification for exclusion & Title of study & Author/Year \\
\hline Insurance scheme not & Effectiveness of public health insurance schemes on & Vongmongkol V, Patcharanarumol W, Panichkriangkrai \\
categorized as MHI & financial risk protection in Thailand: the assessments of & Wurchasers' capacities, contractors' responses and impact on \\
& patients.
\end{tabular}

Other types of health insurance considered in creating impact

Financial protection not entirely attributable to $\mathrm{MHI}$

No co-payments or premiums charged from the beneficiaries

Only abstract available

Not classified as evaluation of impact of $\mathrm{MHI}$ on financial protection
The Impact of Health Insurance Programs on Out-of-Pocket Expenditures in Indonesia: An Increase or a Decrease?

Impact of Health Insurance on Health Care Treatment and Cost in Vietnam: A Health Capability Approach to Financial Protection

The effect of health insurance on financial protection and consumption smoothing: The case of Lebanon

Do health sector reforms have their intended impacts? The World Bank's Health VIII project in Gansu province, China-

The Impact of medical insurance for the poor in Georgia: a regression discontinuity approach

Promoting universal financial protection: health insurance for the poor in Georgia - a case study

An impact evaluation of medical insurance for poor in Georgia: preliminary results and policy implications

Health insurance for the poor: impact on catastrophic and out-of-pocket health expenditures in Mexico

Does Health Insurance promote healthcare access and provide financial protection: empirical evidences from India

Financial Protection in Health Insurance Schemes: A Comparative Analysis of Mediclaim Policy and CHAT Scheme in India
Aji B, De Allegri M, Souares A, Sauerborn R. (2013)

Nguyen KT, Khuat OT, Ma S, Pham DC, Khuat GT, Ruger JP. (2012)

Empirique É. The Effect of Health Insurance on Financial Protection and Consumption Smoothing: The Case of Lebanon. (2009)

Wagstaff A, Yu S. Do health sector reforms have their intended impacts? (2007)

Bauhoff S, Hotchkiss DR, Smith O (2011)

Zoidze A, Rukhadze N, Chkhatarashvili K, Gotsadze G. (2013)

Gotsadze G, Zoidze A, Rukhadze N, Shengelia N, Chkhaidze N. (2015)

Galárraga O, Sosa-Rubí SG, Salinas-Rodríguez A, Sesma-Vázquez S. (2010)

Kumar S. (2015)

Vellakkal S. (2012) and the third studies [22] used data from 6 counties in the two provinces of Ningxia and Shandong. The fourth study [23] used data from the China Health and Nutrition survey conducted in 333 counties where NCMS was implemented. The final study from China reports results of the impact evaluation of NCMS from 189 counties [24]. Three of the included studies are from India, reporting the financial protection provided by four different MHI programs. From these, the Yeshaswini program and the Sampoorna Suraksha Program were both functional in the state of Karnataka and targeted at informal sector workers and general rural population respectively $[25,26]$. SEWA was being operated in Gujarat, with informal female workers and ACCORD in the rural regions of Tamil Nadu [27]. The study on the Yeshaswini program (Aggarwal 2010) was conducted in 82 villages across 16 districts of the state whereas the evaluation of the Sampoorna Suraksha program (Savitha 2013) was conducted in 10 randomly selected taluks across three districts of the state. Nine of the included studies were based on MHI institutions that were operational in Africa; two from Rwanda, one each from Kenya, Tanzania, Uganda, Burkina Faso, Benin and Mali and a cross country study evaluating MHI in Ghana, Mali and Senegal. The two studies from Rwanda used data from an Integrated Living Conditions Survey (ILCS) and ILCS and Rwanda Demographic Health Survey respectively in the 12 provinces of Rwanda [28, 29]. The study from Kenya was conducted across 150 tea centres in Nyeri District of Kenya [30]. The Tanzania study used data from Tanzania Demographic and Health Survey conducted nationwide across 10,300 households, involving men and women aged 15-49 years [31]. In Uganda the evaluation of the Micro care's health insurance scheme was obtained from informal workers in the rural area of Kisiizi and urban centre of Kampala [32]. The study from rural Africa (Parmar 2012) was based on data from 42 villages and 1 town of Burkina Faso [33]. The study from West Africa (Chankova S, Sulzbach S, Diop 2008) was based on three individual studies conducted in the rural district of Nkoranza and Offinso in Ghana, rural district of Bla and urban commune of Sikasso in Mali, and the Thies region in Senegal [34]. Of the two projects grounded in Lao PDR, one was conducted in 87 villages across six districts, encompassing three provinces and the other was conducted in the province of Savannkhet $[35,36]$. In Benin, the evaluation was carried out in a rural zone in the country's Central and Northern areas, in a territory served by 10 MHOs [37]. In Bangladesh, the study was conducted in Madhabpur, Joy Mantap (in district Manikgonj) and Pakutia (in district Tangail) branches of Grameen Bank MHI [38]. The three 
Table 3 Quality assessment of the included studies

\begin{tabular}{|c|c|c|c|c|c|c|c|c|c|c|c|}
\hline Study & $\begin{array}{l}\text { Explicit } \\
\text { aims }\end{array}$ & $\begin{array}{l}\text { Sample size } \\
\text { justification } \\
\text { or } \\
\text { adequate }\end{array}$ & $\begin{array}{l}\text { Justification } \\
\text { sample } \\
\text { representative } \\
\text { of population }\end{array}$ & $\begin{array}{l}\text { Inclusion } \\
\text { and } \\
\text { exclusion } \\
\text { criteria } \\
\text { stated }\end{array}$ & $\begin{array}{l}\text { Reliability } \\
\text { and validity } \\
\text { of } \\
\text { measures } \\
\text { justified }\end{array}$ & $\begin{array}{l}\text { Response } \\
\text { rate and } \\
\text { drop out } \\
\text { specified }\end{array}$ & $\begin{array}{l}\text { Data } \\
\text { adequately } \\
\text { described }\end{array}$ & $\begin{array}{l}\text { Statistical } \\
\text { significance } \\
\text { assessed }\end{array}$ & $\begin{array}{l}\text { Discussion of } \\
\text { generalizability }\end{array}$ & $\begin{array}{l}\text { Null } \\
\text { findings } \\
\text { interpreted }\end{array}$ & TOTAL \\
\hline $\begin{array}{l}\text { Hamid SA, Roberts J, Mosley P. Can micro health } \\
\text { insurance reduce poverty? Evidence from Bangladesh. } \\
\text { Journal of Risk and Insurance. } 2011 \text { Mar 1;78(1):57-82. }\end{array}$ & $Y$ & Y & Y & Y & N & Y & Y & $Y$ & Y & $\mathrm{N}$ & 8 \\
\hline $\begin{array}{l}\text { Yip W, Hsiao WC. Non-evidence-based policy: how ef- } \\
\text { fective is China's new cooperative medical scheme in } \\
\text { reducing medical impoverishment? Social science \& } \\
\text { medicine. } 2009 \text { Jan 31;68(2):201-9. }\end{array}$ & $Y$ & Y & Y & $\mathrm{N}$ & $N$ & $\mathrm{~N}$ & Y & Y & Y & $\mathrm{N}$ & 6 \\
\hline $\begin{array}{l}\text { Hou Z, Van de Poel E, Van Doorslaer E, Yu B, Meng Q. } \\
\text { Effects of NCMS on access to care and financial } \\
\text { protection in China. Health economics. } 2014 \text { Aug } \\
\text { 1;23(8):917-34. }\end{array}$ & $Y$ & Y & Y & Y & $N$ & $\mathrm{~N}$ & $Y$ & Y & Y & $\mathrm{N}$ & 7 \\
\hline $\begin{array}{l}\text { Cheung D, Padieu Y. Heterogeneity of the effects of } \\
\text { health insurance on household savings: Evidence from } \\
\text { rural China. World Development. } 2015 \text { Feb 28;66:84- } \\
103 .\end{array}$ & $Y$ & Y & Y & $Y$ & $Y$ & $\mathrm{~N}$ & Y & Y & Y & Y & 9 \\
\hline $\begin{array}{l}\text { Sun Q, Liu X, Meng Q, Tang S, Yu B, Tolhurst R. } \\
\text { Evaluating the financial protection of patients with } \\
\text { chronic disease by health insurance in rural China. } \\
\text { International Journal for Equity in Health. 2009;8:42. } \\
\text { doi:10.1186/1475-9276-8-42. }\end{array}$ & $Y$ & Y & Y & $Y$ & $Y$ & N & Y & Y & Y & $\mathrm{N}$ & 8 \\
\hline $\begin{array}{l}\text { Wagstaff A, Lindelow M, Jun G, Ling X, Juncheng Q. } \\
\text { Extending health insurance to the rural population: An } \\
\text { impact evaluation of China's new cooperative medical } \\
\text { scheme. Journal of health economics. } 2009 \text { Jan } \\
31 ; 28(1): 1-9 \text {. }\end{array}$ & $N$ & Y & Y & $Y$ & $Y$ & $Y$ & Y & Y & Y & $\mathrm{N}$ & 8 \\
\hline $\begin{array}{l}\text { Aggarwal A. Impact evaluation of India's } \\
\text { 'Yeshasvini'community-based health insurance } \\
\text { programme. Health Economics. } 2010 \text { Sep 1;19(S1):5-35. }\end{array}$ & Y & Y & Y & Y & $N$ & $\mathrm{~N}$ & Y & Y & $\mathrm{N}$ & $\mathrm{N}$ & 6 \\
\hline $\begin{array}{l}\text { Savitha B, KB K. Microhealth insurance and the risk } \\
\text { coping strategies for the management of illness in } \\
\text { Karnataka: a case study. The International journal of } \\
\text { health planning and management. } 2013 \text { Aug } 1 .\end{array}$ & Y & Y & Y & $Y$ & $Y$ & N & Y & Y & Y & $Y$ & 9 \\
\hline $\begin{array}{l}\text { Devadasan N, Criel B, Van Damme W, Ranson K, Van } \\
\text { der Stuyft P. Indian community health insurance } \\
\text { schemes provide partial protection against catastrophic } \\
\text { health expenditure. BMC Health Services Research. } 2007 \\
\text { Mar 15;7(1):43. }\end{array}$ & Y & Y & Y & $Y$ & $Y$ & $N$ & Y & Y & Y & $\mathrm{N}$ & 8 \\
\hline $\begin{array}{l}\text { Wagstaff A. Health insurance for the poor: initial } \\
\text { impacts of Vietnam's health care fund for the poor. } \\
\text { World Bank Policy Research Working Paper. } 2007 \text { Feb } \\
1(4134) \text {. }\end{array}$ & Y & Y & Y & $\mathrm{N}$ & $Y$ & N & Y & Y & $\mathrm{N}$ & $\mathrm{N}$ & 6 \\
\hline
\end{tabular}


Table 3 Quality assessment of the included studies (Continued)

Wagstaff A. Estimating health insurance impacts under $Y$ unobserved heterogeneity: the case of Vietnam's health

care fund for the poor. Health economics. $2010 \mathrm{Feb}$

1;19(2):189-208.

Pham T, Pham TL. Does microinsurance help the poor? Evidence from the targeted health microinsurance

program in Vietnam 2004-2008. International Labor

Organization. 2012 Feb. Research paper No. 11

Alkenbrack S, Lindelow M. The Impact of Community-

Based Health Insurance on Utilization and Out-of-

Pocket Expenditures in Lao People's Democratic

Republic. Health economics. 2013 Dec 1.

Bodhisane S, Pongpanich S. The Impact of Community

Based Health Insurance in Enhancing Better

Accessibility and Lowering the Chance of Having

Financial Catastrophe Due to Health Service Utilization

A Case Study of Savannakhet Province, Laos

International Journal of Health Services. 2015 Jul

20:0020731415595609.

Franco LM, Diop FP, Burgert CR, Kelley AG, Makinen M, Simpara $\mathrm{CH}$. Effects of mutual health organizations on use of priority health-care services in urban and rural

Mali: a case-control study. Bulletin of the World Health

Organization. 2008 Nov;86(11):830-8.

Dercon S, Gunning JW, Zeitlin A, Lombardini S. The

impact of a health insurance programme: Evidence

from a randomized controlled trial in Kenya. Research

Paper. 2012 Nov(24).

Parmar D, Reinhold S, Souares A, Savadogo G,

Sauerborn R. Does Community-Based Health Insurance

Protect Household Assets? Evidence from Rural Africa.

Health services research. 2012 Apr 1:47(2):819-39.

Haddad S, Ridde V, Yacoubou I, Mák G, Gbetié M. An

evaluation of the outcomes of mutual health

organizations in Benin.

Saksena P, Antunes AF, Xu K, Musango L, Carrin G.

Mutual health insurance in Rwanda: evidence on access

to care and financial risk protection. Health policy. 2011

Mar 31:99(3):203-9.

Lu C, Chin B, Lewandowski JL, Basinga P, Hirschhorn LR, Y Hill K, Murray M, Binagwaho A. Towards universal

health coverage: an evaluation of Rwanda Mutuelles in

its first eight years. PLoS One. 2012 Jun 1;7(6):e39282.

Kihaule A. Impact of Micro Health Insurance Plans on Protecting Households Against Catastrophic Health

Y N

6

Y

10

Y

Y

Y

N

N

N

N

N

N

5

N

N

Y

Y

Y

7

Y

Y

Y

N

9

Y

N

N 
Table 3 Quality assessment of the included studies (Continued)

Spending in Tanzania. GSTF Journal of Nursing and

Health Care (JNHC). 2015 Aug 27;2(2)

Dekker M, Wilms A. Health Insurance and Other Risk-

Coping Strategies in Uganda: The Case of Microcare In-

N

N

N

Y

Y

N

4

surance Ltd. World Development. 2010 Mar

31;38(3):369-78.

Chankova S, Sulzbach S, Diop F. Impact of mutual

health organizations: evidence from West Africa. Health

N

N

policy and planning. $2008 \mathrm{Jul}$ 1;23(4):264-76. 
Table 4 Summary of findings

\begin{tabular}{|c|c|c|c|c|}
\hline $\begin{array}{l}\text { Outcome (measure of } \\
\text { financial protection) }\end{array}$ & $\begin{array}{l}\text { Relative } \\
\text { effect }\end{array}$ & $\begin{array}{l}\text { Number of studies and } \\
\text { participants }\end{array}$ & $\begin{array}{l}\text { Quality of evidence } \\
\text { (Quality score) }\end{array}$ & Comments \\
\hline \multirow{3}{*}{$\begin{array}{l}\text { Reduction in OOP } \\
\text { expenditure }\end{array}$} & \multirow{3}{*}{$\begin{array}{l}\text { Not } \\
\text { estimable }\end{array}$} & 13 studies & \multirow{3}{*}{$\begin{array}{l}\text { Moderate quality } \\
\text { (Quality score } 6.8 \text { ) }\end{array}$} & \multirow{20}{*}{$\begin{array}{l}\text { The effect size is not quantifiable as the results in the } \\
\text { majority of studies are not presented statistically. } \\
\text { Individuals (or households where individuals count } \\
\text { is not available) covered by the study may show the } \\
\text { most widely studied outcomes in terms of individuals/ } \\
\text { households covered. The quality of evidence has been } \\
\text { classified as high, moderate and low by taking the } \\
\text { average of the individual study scores for the various } \\
\text { outcomes (refer to Table 3) }\end{array}$} \\
\hline & & $\begin{array}{l}\text { Individuals covered: } \\
202.615 \text { (12 studies) }\end{array}$ & & \\
\hline & & $\begin{array}{l}\text { Households covered: } 2974 \\
\text { (1 study) }\end{array}$ & & \\
\hline \multirow[t]{3}{*}{ Reduction in CHE } & \multirow{3}{*}{$\begin{array}{l}\text { Not } \\
\text { estimable }\end{array}$} & 7 studies & \multirow{3}{*}{$\begin{array}{l}\text { High quality (Quality } \\
\text { Score } 7.9 \text { ) }\end{array}$} & \\
\hline & & $\begin{array}{l}\text { Individuals covered: } 82448 \\
\text { (5 studies) }\end{array}$ & & \\
\hline & & $\begin{array}{l}\text { Households covered: } 3226 \\
\text { (2 studies) }\end{array}$ & & \\
\hline \multirow{2}{*}{$\begin{array}{l}\text { Reduction in total } \\
\text { health expenditures }\end{array}$} & \multirow{2}{*}{$\begin{array}{l}\text { Not } \\
\text { estimable }\end{array}$} & 3 studies & \multirow{2}{*}{$\begin{array}{l}\text { Moderate quality } \\
\text { (Quality score 6.8) }\end{array}$} & \\
\hline & & $\begin{array}{l}\text { Individuals covered: } 51599 \\
\text { (3 studies) }\end{array}$ & & \\
\hline \multirow[t]{2}{*}{ Reduction in poverty } & \multirow{2}{*}{$\begin{array}{l}\text { Not } \\
\text { estimable }\end{array}$} & 2 studies & \multirow{2}{*}{$\begin{array}{l}\text { Moderate quality } \\
\text { (Quality score } 7.0 \text { ) }\end{array}$} & \\
\hline & & $\begin{array}{l}\text { Households covered: } 5709 \\
\text { (2 studies) }\end{array}$ & & \\
\hline \multirow{2}{*}{$\begin{array}{l}\text { Improvement in } \\
\text { consumption patterns }\end{array}$} & \multirow{2}{*}{$\begin{array}{l}\text { Not } \\
\text { estimable }\end{array}$} & 1 study & \multirow{2}{*}{$\begin{array}{l}\text { Moderate quality } \\
\text { (Quality score } 7.0 \text { ) }\end{array}$} & \\
\hline & & Individuals covered: 145 & & \\
\hline \multirow{3}{*}{$\begin{array}{l}\text { Protection of } \\
\text { household assets }\end{array}$} & \multirow{3}{*}{$\begin{array}{l}\text { Not } \\
\text { estimable }\end{array}$} & 4 studies & \multirow{3}{*}{$\begin{array}{l}\text { Moderate quality } \\
\text { (Quality score 6.8) }\end{array}$} & \\
\hline & & $\begin{array}{l}\text { Individuals covered: } 43499 \\
\text { (3 studies) }\end{array}$ & & \\
\hline & & $\begin{array}{l}\text { Households covered: } 890 \\
\text { (1 study) }\end{array}$ & & \\
\hline \multirow{3}{*}{$\begin{array}{l}\text { Protection of household } \\
\text { savings }\end{array}$} & \multirow{3}{*}{$\begin{array}{l}\text { Not } \\
\text { estimable }\end{array}$} & 3 studies & \multirow{3}{*}{$\begin{array}{l}\text { High quality (Quality } \\
\text { score 8.0) }\end{array}$} & \\
\hline & & $\begin{array}{l}\text { Individuals covered: } 26591 \\
\text { (2 studies) }\end{array}$ & & \\
\hline & & $\begin{array}{l}\text { Households covered: } 1312 \\
\text { (1 study) }\end{array}$ & & \\
\hline \multirow{2}{*}{$\begin{array}{l}\text { Reduction in household } \\
\text { borrowings }\end{array}$} & \multirow{2}{*}{$\begin{array}{l}\text { Not } \\
\text { estimable }\end{array}$} & 4 studies & \multirow{2}{*}{$\begin{array}{l}\text { Moderate quality } \\
\text { (Quality score 7.3) }\end{array}$} & \\
\hline & & $\begin{array}{l}\text { Individuals covered: } \\
\text { 43644(4 studies) }\end{array}$ & & \\
\hline
\end{tabular}

Quality of evidence criteria: score of $\leq 5$ is low; score of ' 5 and $\leq 7.5$ is moderate; and score of $\geq 7.6$ is high

studies from Vietnam report the measures of financial protection among the beneficiaries of Vietnam's Health Care Fund for the Poor, using data from a series of household surveys (Vietnam Households Living Standard Surveys) conducted in all provinces (rural and urban) of the country [39-41].

\section{Study designs}

Out of the 23 studies, 20 studies used cross sectional study design. Only two studies, conducted in Kenya and Burkina Faso, used a randomized control trial study design [30], while the one study conducted in Mali was a case control study [34]. Two of the cross sectional studies, used the cross sectional data to compare two different MHI schemes while 16 cross-sectional studies were based on a comparison between insured and uninsured. From these 16 cross sectional studies, six used the technique of propensity score matching and one study [40] used triple difference with matching to match the characteristics of the two comparison groups (insured and uninsured), in order to mitigate possible selection bias that could have occurred.

\section{Measures of financial protection and outcomes}

Finally, the analysis of the 23 studies included in the review, resulted in the identification of following measures of financial protection. 1) OOP 2) CHE 3) Total health expenditures 4) Poverty 5) Consumption patterns 6) Household assets 7) Household savings (Table 4).

\section{Out of pocket expenditure}

Thirteen out of the 23 included studies have used reduced OOP expenditure on health as the measure for assessing the financial protection provided by MHI.

Studies from Tanzania, Uganda and Benin, done to evaluate effects of MHI by comparing insured versus un- 
Table 5 Methodological details and key findings of the included studies

Country/Target

Name of MHI Scheme

Study design, sampling

technique, evaluationg

Measure of financial

Key findings/

Hamid SA, Roberts J,

Bangladesh/Poor

Grameen Bank MHI

the addition of MHI households

Cross sectional,

health insurance

to the microcredit

Multistage sampling,

Poverty

Positive association

reduce poverty?

programs of GB has

Bangladesh. Journal of

an effect on poverty

program and control

areas

Risk and Insurance.

2011 Mar 1:78(1):57-

82.

2 Yip W, Hsiao WC. Nonevidence-based policy: how effective is China's new cooperative medical scheme in reducing medical im-

poverishment? Social

science \& medicine.

$2009 \operatorname{Jan} 31 ; 68(2): 201$

9.

3 Hou Z, Van de Poel E,

Van Doorslaer $\mathrm{E}_{\text {, }} \mathrm{Yu} \mathrm{B}$

Meng Q. Effects of

NCMS on access to

care and financial

protection in China

Health economics.

2014 Aug 1;23(8):917

34

\begin{abstract}
To assess the
effectiveness of the

NCMS model in

reducing medical
\end{abstract}

impoverishment

To identify the

impact of NCMS on access to care and financial protection by exploiting the

variation in NCMS

design across

counties.
China/Rural New Cooperative Medical Scheme (NCMS)

Comparison study,

Convenience sampling,

Comparison between two

study (insurance) groups

1. Household income, found between

2. Household non MHl and household

income assets, income, ownership

4. Food sufficiency of assets, food

being above or below poverty reduction.

the poverty line Result was statistically

Result was statistically

significant for food
sufficiency only

NCMS reduced

poverty headcount

by $3.5-3.9 \%$

The RMHC would

reduce poverty

by $8.3-13.1 \%$

Cross sectional,

Calculation of

scheme generosity

based on (i) the copayment;

(ii) the reimbursement rate;

and (iii) the ceiling.

4 Cheung D, Padieu Y. Heterogeneity of the effects of health

insurance on

household savings:

Evidence from rural

China. World

Development. 2015

Feb 28:66:84-103.
To explore the

heterogeneity of the

impact of NCMS on

household savings

across income

groups in rural China.
Cross sectional

Purposive sampling,

Comparison between

income quartiles, Propensity

Score Matching
OOP expenditure

No effects found

on spending in

the full sample,

but conditional

upon use

NCMS reduces

the share of OOP

spending for an

outpatient visit

and increases

OOP spending

per inpatient stay

(among users)

Total spending

per hospitalization

had increased

(among users)

Higher middle-

income participants

deplete their savings

significantly compared

to non-participant

households.

This difference

suggests a decrease

in savings secondary

to reduction of

household patrimony.

.


5 Sun $\mathrm{Q}$, Liu X, Meng Q, Tang S, Yu B, Tolhurst R. Evaluating the

financial protection of patients with chronic disease by health insurance in rural China. International Journal for Equity Health. 2009;8:42. doi:10.1186/1475-9276-

6 Wagstaff $A$, Lindelow $M$, Jun $G$, Ling $X$ Juncheng $Q$.

Extending health

insurance to the rural population: An impact

new cooperative

new cooperative

Journal of health

economics. 2009 Jan 31;28(1):1-9.
To investigate the extent to which

\section{China/Rural}

households

patients suffering with chronic

from chronic disease illness patients

in rural China face

catastrophic

expenditure on

healthcare, and how

far the New Co-

operative Medical In-

surance Scheme

(NCMS) offers them

financial protection

against this.
Cross Sectional,

Multistage sampling:

County: Township:

Comparison between

insured and non insured
CHE

Cross Sectional,

Multi-stage stratified

random sampling,

Comparison

between insured

and non insured,

Propensity score

matching

Higher middle-

income participants

save less than

non-participants

There was no

impact of the

health care scheme

on the poorest and

richest households.

Between 8 and $11 \%$

of non-NCMS

members and

$13 \%$ of NCMS

members did

not seek any

medical care

for chronic illness.

A greater

proportion of

NCMS members

in the poorest

quintile faced

CHE as compared to

those in the richest

quintile

Overall a slightly

higher proportion of

non-NCMS

members than

NCMS member

households faced

CHE but

the difference

was not statistically significant.

The overall household

OOP spending on

health care

does not appear

to have been

investigate the issue

of how the

characteristics of

different NCMS

schemes - their
generosity and which

generosity

reimbursable_-affect

their impact.

reduced by NCMS.

cost of delivery was

reduced by NCMS.

Cost of OPD was not

reduced. NCMS

appears to have

resulted in people

receiving more

expensive health

care per visit. 
Table 5 Methodological details and key findings of the included studies (Continued)

\begin{tabular}{|c|c|c|c|c|c|c|c|}
\hline 7 & $\begin{array}{l}\text { Aggarwal A. Impact } \\
\text { evaluation of India's } \\
\text { Yeshasvini'community- } \\
\text { based health insurance } \\
\text { programme. Health } \\
\text { Economics. } 2010 \text { Sep } \\
\text { 1;19(S1):5-35./ }\end{array}$ & $\begin{array}{l}\text { To evaluate the } \\
\text { impact of India's } \\
\text { Yeshasvini } \\
\text { community-based } \\
\text { health insurance } \\
\text { programme on } \\
\text { health-care } \\
\text { utilization, financial } \\
\text { protection, treatment } \\
\text { outcomes and eco- } \\
\text { nomic well-being. }\end{array}$ & $\begin{array}{l}\text { India/Cooperative } \\
\text { rural farmers and } \\
\text { informal sector } \\
\text { workers }\end{array}$ & Yeshasvini & $\begin{array}{l}\text { Cross sectional, } \\
\text { Multi stage random } \\
\text { sampling, Comparison } \\
\text { between intervention } \\
\text { and control groups, } \\
\text { Propensity score matching }\end{array}$ & $\begin{array}{l}\text { Borrowing } \\
\text { Sale of assets } \\
\text { Household Savings } \\
\text { Overall health } \\
\text { expenditures }\end{array}$ & $\begin{array}{l}\text { Total borrowings } \\
\text { are } 36 \% \text { and } 30 \% \\
\text { less for enrollees. } \\
\text { The payments } \\
\text { made out of } \\
\text { savings, incomes, } \\
\text { and other sources, } \\
\text { on the other hand, } \\
\text { are up to } 74 \% \\
\text { less for enrollees. } \\
\text { Borrowings and/or } \\
\text { asset sales associated } \\
\text { with primary } \\
\text { health-care } \\
\text { use are } 61 \% \\
\text { lower for the } \\
\text { relatively worse-off } \\
\text { group among the i } \\
\text { nsured. } \\
\text { Overall health } \\
\text { expenditures } \\
\text { are } 19-20 \% \\
\text { higher for YH } \\
\text { enrollees compared } \\
\text { with uninsured } \\
\text { cooperatives }\end{array}$ \\
\hline 8 & $\begin{array}{l}\text { Savitha B, KB K. } \\
\text { Microhealth insurance } \\
\text { and the risk coping } \\
\text { strategies for the } \\
\text { management of illness } \\
\text { in Karnataka: a case } \\
\text { study. The } \\
\text { International journal of } \\
\text { health planning and } \\
\text { management. } 2013 \\
\text { Aug 1./ }\end{array}$ & $\begin{array}{l}\text { To evaluate the } \\
\text { impact of } \\
\text { SampoornaSuraksha } \\
\text { Program, on risk } \\
\text { coping strategies of } \\
\text { households faced } \\
\text { with medical illness } \\
\text { in Karnataka state, } \\
\text { India }\end{array}$ & $\begin{array}{l}\text { India/Rural } \\
\text { population }\end{array}$ & Sampoorna Suraksha & $\begin{array}{l}\text { Cross sectional descriptive, } \\
\text { Multistage cluster sampling }\end{array}$ & $\begin{array}{l}\text { Borrowing } \\
\text { Household savings } \\
\text { Sale of assets; }\end{array}$ & $\begin{array}{l}\text { A lower percentage } \\
\text { of insured individuals } \\
(57.2 \%) \text { relied on } \\
\text { borrowing compared } \\
\text { with newly insured } \\
(79.5 \%) \text { or uninsured } \\
\text { individuals ( } 75.2 \%) \\
(p<0.05) \text {. } \\
\text { Insured individuals } \\
\text { used more savings } \\
\text { (32.7\%) than newly } \\
\text { insured ( } 24.7 \%) \\
\text { ( } p>0.05) \text {. } \\
\text { Sale of assets was } \\
\text { found to be high } \\
\text { in insured group } \\
\text { than in newly } \\
\text { insured but lower } \\
\text { than that in } \\
\text { uninsured groups } \\
\text { ( } p>0.05) \text {. } \\
\text { The odds of the } \\
\text { incidence of } \\
\text { borrowing } \\
\text { increased }\end{array}$ \\
\hline
\end{tabular}


Table 5 Methodological details and key findings of the included studies (Continued)

9 Devadasan N, Criel B,

Van Damme W,

Ranson K, Van der

Stuyft P. Indian

community health

provide partial

protection against

catastrophic health

expenditure. BMC

Health Services

Research. 2007 Mar

15;7(1):43

10 Wagstaff A. Health insurance for the poor: initial impacts of Vietnam's health care fund for the poor.

World Bank Policy

Research Working

Paper. 2007 Feb

1 (4134).

11 Wagstaff A. Estimating

health insurance

impacts under

unobserved

heterogeneity: the

case of Vietnam's

health care fund for

the poor. Health

economics. 2010 Feb

1;19(2):189-208.
To determine

whether insured

households are

protected from

catastrophic health

\section{ndia/ACCORD \\ rural population}

informal workers

ACCORD \& SEWA

Cross sectional

Desk review of

claims register

Comparison between

two health insurance

schemes

To estimate the

impact of HCFP by

comparing out-of-

and utilization be-

by HCFP and com-

parable individuals

not covered.

To estimate the

impact of Vietnam's

health insurance

program for poor

households (health

care fund for the

poor, or HCFP) in a

way that is robust to

the biases introduced

by unobserved

heterogeneity.

\section{Vietnam/Poor}

households,

households in

poor localities,

Health Care Fund for the Poor (HCFP)

Cross Sectional

Comparison between of

insured and uninsured,

Propensity Score Matching

Cross Sectional,

insured and uninsured

Triple differencing with

matching
Comparison between

by a factor of 4.636

in newly insured

and by a factor of

6.407 in uninsured

compared with the

insured individual

$67 \%$ of ACCORD

and $34 \%$ of SEWA

members protected

from OOP payments

$8 \%$ (currently at

$3.5 \%)$ at ACCORD

and $49 \%$ at SEWA

(currently $23 \%$ )

would have

experienced CHE

in the absence of

an insurance scheme.

HCFP reduces the

risk of catastrophic

OOP spending.

There was no

perceptible impact

on (average) OOP

spending,

OOP expenditure

HCFP appears to

have reduced OOP

spending on

health care

considerably,

A significant

impact on OOP

spending is not

evident in a single

difference, i.e.

comparing

spending in

2006 across the

treated and

control groups.

It is evident in

a double

difference - i.e.

2004-2006 change

across the two

groups 
Table 5 Methodological details and key findings of the included studies (Continued)

\begin{tabular}{|c|c|c|c|c|c|c|c|}
\hline 12 & $\begin{array}{l}\text { Pham T, Pham TL. } \\
\text { Does microinsurance } \\
\text { help the poor? } \\
\text { Evidence from the } \\
\text { targeted health } \\
\text { microinsurance } \\
\text { program in Vietnam } \\
\text { 2004-2008. } \\
\text { International Labor } \\
\text { Organization. } 2012 \\
\text { Feb. Research paper } \\
\text { No. } 11\end{array}$ & $\begin{array}{l}\text { To assess whether } \\
\text { HCFP program } \\
\text { improves health care } \\
\text { seeking behavior of } \\
\text { the poor with } \\
\text { respect to access to } \\
\text { health care, OOP } \\
\text { spending, and } \\
\text { preventive care } \\
\text { behavior; }\end{array}$ & & & $\begin{array}{l}\text { Cross sectional, } \\
\text { Stratified random } \\
\text { cluster sampling, } \\
\text { Impact Evaluation: } \\
\text { using impact measures of } \\
\text { Intention to treat effect, } \\
\text { and treatment effect of } \\
\text { the treated }\end{array}$ & $\begin{array}{l}\text { OOP expenditure } \\
\text { CHE }\end{array}$ & $\begin{array}{l}\text { MHI reduced the } \\
\text { OOP health care } \\
\text { expenditure of } \\
\text { poor participants, } \\
\text { through a price } \\
\text { reduction effect. } \\
\text { propensity of } \\
\text { having a CHE } \\
\text { is lowered by } \\
19 \% \text { among insured }\end{array}$ \\
\hline 13 & $\begin{array}{l}\text { Alkenbrack S, Lindelow } \\
\text { M. The Impact of } \\
\text { Community-Based } \\
\text { Health Insurance on } \\
\text { Utilization and Out-of- } \\
\text { Pocket Expenditures in } \\
\text { Lao People's } \\
\text { Democratic Republic. } \\
\text { Health economics. } \\
2013 \text { Dec } 1\end{array}$ & $\begin{array}{l}\text { To estimate the MHI } \\
\text { program's impact on } \\
\text { utilization and out-of- } \\
\text { pocket expenditures }\end{array}$ & $\begin{array}{l}\text { Lao PDR/Informal } \\
\text { workers }\end{array}$ & $\begin{array}{l}\text { CBHI implemented } \\
\text { by MoH }\end{array}$ & $\begin{array}{l}\text { Cross sectional, } \\
\text { two-stage cluster sampling, } \\
\text { Comparison between } \\
\text { insured and uninsured, } \\
\text { Propensity Score matching }\end{array}$ & $\begin{array}{l}\text { Health expenditures } \\
\text { CHE }\end{array}$ & $\begin{array}{l}\text { CBHI members' total } \\
\text { payments, } \\
\text { conditional on } \\
\text { any use, were } \\
\text { less than those } \\
\text { of the uninsured } \\
\text { ( } \$ 62.71 \text { for } C B H \\
\text { versus } \$ 98.70 \text { for } \\
\text { non-CBHI members). } \\
14.7 \% \text { of insured } \\
\text { inpatient service } \\
\text { users live in } \\
\text { households with } \\
\text { CHE } \\
\text { compared with } \\
27.4 \% \text { of } \\
\text { uninsured } \\
\text { inpatient users }\end{array}$ \\
\hline 14 & $\begin{array}{l}\text { Bodhisane S, } \\
\text { Pongpanich S. The } \\
\text { Impact of Community } \\
\text { Based Health } \\
\text { Insurance in } \\
\text { Enhancing Better } \\
\text { Accessibility and } \\
\text { Lowering the Chance } \\
\text { of Having Financial } \\
\text { Catastrophe Due to } \\
\text { Health Service } \\
\text { Utilization A Case } \\
\text { Study of Savannakhet } \\
\text { Province, Laos. } \\
\text { International Journal of } \\
\text { Health Services. } 2015\end{array}$ & $\begin{array}{l}\text { To determine the } \\
\text { role of community- } \\
\text { based health insur- } \\
\text { ance in making } \\
\text { health care services } \\
\text { accessible and in pre- } \\
\text { venting financial ca- } \\
\text { tastrophe resulting } \\
\text { from personal pay- } \\
\text { ment for inpatient } \\
\text { services. }\end{array}$ & $\begin{array}{l}\text { Lao PDR/Informal } \\
\text { sector }\end{array}$ & & $\begin{array}{l}\text { Cross sectional, } \\
\text { simple random sampling } \\
\text { 'Comparison between insured } \\
\text { and uninsured }\end{array}$ & CHE & $\begin{array}{l}\text { There was no } \\
\text { difference in terms } \\
\text { of probability } \\
\text { of financial } \\
\text { catastrophe from } \\
\text { health service } \\
\text { utilization between } \\
\text { insured and } \\
\text { uninsured } \\
\text { households. } \\
\text { Insurance status } \\
\text { does not significantly } \\
\text { improve accessibility } \\
\text { and financial } \\
\text { protection against } \\
\text { CHE }\end{array}$ \\
\hline
\end{tabular}


Table 5 Methodological details and key findings of the included studies (Continued)

\begin{tabular}{|c|c|c|c|c|c|c|c|c|}
\hline 15 & $\begin{array}{l}\text { Franco LM, Diop FP, } \\
\text { Burgert CR, Kelley AG, } \\
\text { Makinen M, Simpara } \\
\text { CH. Effects of mutual } \\
\text { health organizations } \\
\text { on use of priority } \\
\text { health-care services in } \\
\text { urban and rural Mali: a } \\
\text { case-control study. } \\
\text { Bulletin of the World } \\
\text { Health Organization. } \\
\text { 2008 Nov;86(11):830- } \\
\text { 8./ }\end{array}$ & Africa & $\begin{array}{l}\text { To examine the } \\
\text { effects of a } \\
\text { community-based } \\
\text { mutual health } \\
\text { organization (MHO) } \\
\text { on utilization of pri- } \\
\text { ority health services, } \\
\text { financial protection } \\
\text { of its members and } \\
\text { inclusion of the poor } \\
\text { and other target } \\
\text { groups. }\end{array}$ & $\begin{array}{l}\text { Mali/Informal } \\
\text { sector }\end{array}$ & $4 \mathrm{MHOS}$ & $\begin{array}{l}\text { Case control, } \\
\text { Simple random sampling, } \\
\text { Desk review,Comparison } \\
\text { between member and } \\
\text { non-member households }\end{array}$ & $\begin{array}{l}\text { Health expenditures } \\
\text { OOP expenditure }\end{array}$ & $\begin{array}{l}\text { Lower household } \\
\text { health expenditures } \\
\text { as a percentage of } \\
\text { overall cash } \\
\text { consumption and } \\
\text { lower OOP } \\
\text { payments for fever } \\
\text { treatments were } \\
\text { reported among } \\
\text { the insured. } \\
\text { Health expenditure } \\
\text { out of total cash is } \\
5.6 \text { to } 6.4 \text { in } \mathrm{MHO} \\
\text { members and } 6.2 \\
\text { to } 8.9 \% \text { in } \\
\text { non members }\end{array}$ \\
\hline 16 & $\begin{array}{l}\text { Dercon S, Gunning JW, } \\
\text { Zeitlin A, Lombardini } \\
\text { S. The impact of a } \\
\text { health insurance } \\
\text { programme: Evidence } \\
\text { from a randomized } \\
\text { controlled trial in } \\
\text { Kenya. Research Paper. } \\
2012 \text { Nov(24)./ }\end{array}$ & & $\begin{array}{l}\text { To investigate the } \\
\text { impact of Bimaya } \\
\text { Jamali health } \\
\text { insurance on health } \\
\text { care utilization and } \\
\text { health care } \\
\text { outcomes, and a } \\
\text { variety of outcomes } \\
\text { not directly related } \\
\text { to health. }\end{array}$ & $\begin{array}{l}\text { Kenya/Informal } \\
\text { sector/tea farmers }\end{array}$ & $\begin{array}{l}\text { Wananchi Savings and Credit } \\
\text { Cooperative Society/Bimaya } \\
\text { Jamali }\end{array}$ & Randomized Controlled Trial & $\begin{array}{l}\text { Health expenditures } \\
\text { Borrowing } \\
\text { Household } \\
\text { consumption }\end{array}$ & $\begin{array}{l}\text { Positive impact } \\
\text { of MHI was } \\
\text { reported on } \\
\text { 1. Net health } \\
\text { expenditures } \\
\text { 2. Informal } \\
\text { borrowing for } \\
\text { medical costs } \\
\text { 3. Food consumption } \\
\text { 4. Non-food } \\
\text { consumption } \\
\text { 5. Overall consumption }\end{array}$ \\
\hline 17 & $\begin{array}{l}\text { Parmar D, Reinhold S, } \\
\text { Souares A, Savadogo } \\
\text { G, Sauerborn R. Does } \\
\text { Community-Based } \\
\text { Health Insurance Pro- } \\
\text { tect Household Assets? } \\
\text { Evidence from Rural } \\
\text { Africa. Health services } \\
\text { research. 2012 Apr } \\
\text { 1;47(2):819-39./ }\end{array}$ & & $\begin{array}{l}\text { To evaluate whether } \\
\text { community-based } \\
\text { health insurance } \\
\text { (CBHI) protects } \\
\text { household assets in } \\
\text { rural Burkina Faso, } \\
\text { Africa }\end{array}$ & $\begin{array}{l}\text { Burkina Faso/Rural } \\
\text { population }\end{array}$ & $\begin{array}{l}\text { Assurance Maladie à } \\
\text { Base Communautaire }\end{array}$ & $\begin{array}{l}\text { Randomized controlled trial } \\
\text { Random sampling }\end{array}$ & Household assets & $\begin{array}{l}\text { MHI seemed to } \\
\text { protect and } \\
\text { increase household } \\
\text { assets } \\
7 \% \text { increase in } \\
2006 \text { and } 16 \% \\
\text { increase in } 2007 \\
\text { was recorded. }\end{array}$ \\
\hline 18 & $\begin{array}{l}\text { Haddad S, Ridde V, } \\
\text { Yacoubou I, Mák G, } \\
\text { Gbetié M. An } \\
\text { evaluation of the } \\
\text { outcomes of mutual } \\
\text { health organizations in } \\
\text { Benin. }\end{array}$ & & $\begin{array}{l}\text { To evaluate the } \\
\text { benefits attributable } \\
\text { to membership in a } \\
\text { mutual health } \\
\text { organization in a } \\
\text { rural region of Benin. }\end{array}$ & $\begin{array}{l}\text { Benin/Rural low } \\
\text { income households }\end{array}$ & $10 \mathrm{MHOs}$ & $\begin{array}{l}\text { Cross sectional, } \\
\text { Purposive and } \\
\text { convenience } \\
\text { sampling;Document } \\
\text { review,Comparison } \\
\text { between intervention } \\
\text { and control groups }\end{array}$ & $\mathrm{OOP}$ & $\begin{array}{l}\text { MHI significantly } \\
\text { reduced } \\
\text { hospitalization } \\
\text { expenses among } \\
\text { members. } \\
\text { Particular benefits } \\
\text { to the poor were } \\
\text { not proven. }\end{array}$ \\
\hline 19 & $\begin{array}{l}\text { Saksena P, Antunes AF, } \\
\text { Xu K, Musango L, } \\
\text { Carrin G. Mutual health }\end{array}$ & & $\begin{array}{l}\text { To examine the } \\
\text { effect of mutual } \\
\text { health insurance }\end{array}$ & $\begin{array}{l}\text { Rwanda/Mainly } \\
\text { informal sector }\end{array}$ & Not mentioned & $\begin{array}{l}\text { Cross sectional, } \\
\text { Comparison between } \\
\text { insured and uninsured }\end{array}$ & $\begin{array}{l}\text { OOP expenditure } \\
\text { Financial burden }\end{array}$ & $\begin{array}{l}\text { Insured households } \\
\text { spent significantly } \\
\text { less OOP: only }\end{array}$ \\
\hline
\end{tabular}


Table 5 Methodological details and key findings of the included studies (Continued)

$\begin{array}{ll}\text { insurance in Rwanda: } & (\mathrm{MHI}) \text { on utilization } \\ \text { evidence on access to } & \text { of health services } \\ \text { care and financial risk } & \text { and financial risk } \\ \text { protection. Health } & \text { protection. } \\ \text { policy. 2011 Mar } & \end{array}$

policy. $2011 \mathrm{Mar}$

protection

31;99(3):203-9./

20 Lu C, Chin B,

$L R$, Hill K, Murray M,

Binagwaho A. Towards

universal health

Mutuelles in its first

eight years. PLOS One.

2012 Jun 1;7(6):e39282.

21 Kihaule A. Impact of

Micro Health Insurance

Plans on Protecting

Households Against

GSTF Journal of

Nursing and Health 27;2(2

22 Dekker M, Wilms A.

Health Insurance and

Other Risk-Coping

Strategies in Uganda:

The Case of Microcare

Insurance Ltd. World

Mar 31;38(3):369-78.
Lewandowski J

Basinga $\mathrm{P}$, Hirschhorn

evaluation of Rwanda

Catastrophic Health

Care (JNHC). 2015 Aug

Development. 2010

\author{
To evaluate the \\ impact of Mutuelles \\ $\begin{array}{ll}\text { impact of Mutuelles } & \text { Population } \\ \text { on achieving } & \text { Children Unde }\end{array}$ \\ 5 Years \\ medical services and Pregnant women \\ financial risk \\ eight years of \\ implementation
}

To analyze whether

households'

Tanzania/Rural and

health insurance

funds provide them

with the protection

against catastrophic

health spending

when sick.

\section{To explore the}

elationship between

health insurance and

other risk-coping

strategies used to

formal sector (study

finance medical

informal sector

expenditures in

Uganda.

\section{Mutelles}

Not mentioned

OOP expenditure
Cross sectional,

Comparison between

insured

and uninsured,

Propensity Score

matching

Cross sectional

Comparison between

insured and uninsured

$\mathrm{HE}$

OP expenditure

$\mathrm{CHE}$

(1)

$3.5 \%$ of their CTP

compared to $6.6 \%$

for non-insured

households.

Households insured

with MHI had a

lower financial

burden, with

only $20.1 \%$ of

them spending

over $10 \%$ compared

to $41.6 \%$ for

non-insured.

The average annual

household OOP

spending for insured

was significantly lower

(5,744 RWF) than

that of the uninsured

households

(8,755 RWF).

The percentage of

the insured

households with

CHE (5.1\%)

was significantly lower

than that (10.5\%) of

uninsured households.

Insured households

were protected

against CHE during

episodes of illness

Reduction in OOP

expenditure among

the members

was reported

Cross sectional,

Convenience sampling

OOP expenditure

Sale of assets

OOP expenditures

on health care

were significantly

higher in the

uninsured

households: USh

186,640 (US\$ 100.88)

in last 12 months

compared to the

insured households

USh 83,420

(US\$ 45.09). $44 \%$ of 
23 Chankova S, Sulzbach S, Diop F. Impact of mutual health

evidence from West Africa. Health policy and planning. $2008 \mathrm{Ju}$ 1;23(4):264-76.
To add to the limited Ghana, Mali, Senegal/ Ghana: 1 MHO: Nkoranza Health Cross sectional, evidence on the Households registered Insurance Scheme Mali: Comparison between
impact of MHOs on and not registered in 4 MHOs: Bougoulaville, insured and insured
pocket payments. 3 study sides serving Wayerma, Kemeni, Blaville Senegal: households $27 \mathrm{MHOs}$-all MHOs in Thies region that had $\begin{array}{ll}\text { and comparison } & \text { in Thies region that had } \\ \text { groups } & \text { been operational in the } \\ & 2 \text { years preceding the study }\end{array}$

the uninsured

insured had enough

cash to pay for

health care.

Uninsured households

sold assets worth

USh 138,940

(US\$ 75.10)

while insured

households sold

USh 35,030

(US\$ 18.94) worth

of assets.

OOP expenditure

per illness was

USh 31,252

(US\$ 16.89)

lower for insured

households.

Insured borrowed

less money per

illness (a reduction

of USh 42,828 or

US\$23.15)

OOP expenditure In Ghana, hospital

OOP expenditure

averaged US\$2

among insured,

compared with

US\$44 for non-

beneficiaries. In

Senegal, inpatient

OOP expenditures

was US\$61 for MHO

members, US\$234

for non-members.

There was no

difference in

OOP expenditures

for outpatient care

between $\mathrm{MHO}$

members and

non-members

in Ghana, Mali

and Senega 
insured households, showed that members of the health insurance scheme incur much less OOP, at the point of service, when seeking health care. In Uganda, the uninsured households, had spent USh 186,640 (US\$ 100.88) on average, in the last 12 months, compared to the households insured by Microcare insurance, who had spent a much lower amount of USh 83,420 (US\$ 45.09) [32].

In India, it was found that $67 \%$ of insured households at ACCORD MHI scheme and $34 \%$ of insured households at SEWA MHI scheme were protected from making OOP payments for healthcare [27].

In Vietnam, participation in the Health Care Fund for the Poor (HCFP) showed differential effects on the OOP health expenditure of poor participants at different stages of the scheme. The World Bank Policy Research Paper of 2007, showed that HCFP had no impact on OOP, and the poor end up spending a significant proportion of their incomes on healthcare [39]. In 2010, Wagstaff [40] again stated that a significant impact on OOP expenditure could only be proven in a double difference, that is comparing the 2004-2006 change across the treatment and the control groups, but not in a single difference (just the difference in spending in a single year across the 2 groups). The ILO research paper (2012) however, showed a significant reduction in OOP expenditure among the insured, through a price reduction effect [41].

A study by Saksena et al in Rwanda revealed that MHI enrollment contributes towards diminishing financial burden on the enrolled households. The study defined financial burden as ratio of OOP expenditure to capacityto-pay (CTP). The households insured with MHI scheme spent only $3.5 \%$ OOP out of their total CTP whereas the uninsured households spent $6.6 \%$. Only $20.1 \%$ of the insured households spent beyond $10 \%$ of their CTP compared to $41.6 \%$ of the non-insured [28].

On the contrary, few studies depict that MHI has only been partially effective in reducing OOP or CHE. In China, NCMS was launched to alleviate enrollees' monetary burden and shield from medical impoverishment. A study done to evaluate the impact of the NCMS scheme in rural China, found that NCMS reduces the OOP expenditure at the outpatient level but raises it at the inpatient level alongside total spending per episode of hospitalization [21]. Similar findings were reported by another study where it was concluded that even though cost of deliveries was reduced by NCMS, the OOP expenditure on OPD and other inpatient services did not drop [24].

A case control study from Mali [42] conducted to study the impact of membership in four MHOs showed that there was reduced OOP expenditure among the insured for fever treatments only. Similarly, a study conducted in three West African countries of Ghana, Mali and Senegal showed decline in OOP among the insured for hospitalization only [34]. In Ghana, the cost of an event of hospitalization varied significantly between beneficiaries and non-beneficiaries, which was $\$ 2$ and $\$ 44$ respectively. In Senegal this amount was $\$ 61$ for beneficiaries and $\$ 235$ for non-beneficiaries. In these countries, MHO membership did not appear to have a significant effect on OOP expenditures for curative outpatient care as the expenses incurred were almost the same for members and non-members [34].

\section{Catastrophic health expenditures}

Our results are suggestive of a likely association between MHI and CHE. In Tanzania, MHI was proven to be providing financial protection to the member households against $\mathrm{CHE}$ during episodes of illness [with a CHE coefficient of $-0.0686(p=0.04)$ for the poor households and $-0.08015(\mathrm{p}=0.022$ for the non-poor households)], where $\mathrm{CHE}$ had been defined as OOP spending on health care that exceeds 25 percent of the total household budget [31].

A study from India revealed that in the absence of community based health insurance, $8 \%$ of the households insured with ACCORD MHI scheme and $49 \%$ with SEWA MHI scheme would have faced CHE [27].

In Vietnam also, a study reveals that HCFP MHI program, helped reduce the incidence of $\mathrm{CHE}$ when dealing with adverse health events, by increasing the overall health awareness among the beneficiaries that encouraged them to go for more regular medical checkups [39].

The second included study from Rwanda, studying the effect of Mutelles, a mutual health organization proved that the proportion of the insured households with CHE (5.1 percent) was considerably lower than that (10.5 percent) of uninsured households with CHE [29]. Similar findings were reported from Lao PDR, where it was found that $14.7 \%$ of insured inpatient service users live in households with CHE compared with $27.4 \%$ of uninsured inpatient users [36]. In contrast, another study done on the members of the same CBHI scheme in Lao PDR, but in a different province of the country, showed that there was no difference in the probability of financial catastrophe from health expenditures between insured and uninsured households [35].

In China, a study showed that among the households with chronic diseased patients, slightly higher proportion of non-NCMS member households than NCMS member households faced catastrophic expenditure, but the difference was not statistically significant [22].

\section{Total health expenditures}

The study conducted in west African country of Mali, showed that the MHO membership was associated with 
lower household health expenditures as a percentage of overall cash consumption [42].

In contrast, the paper from India, based on the Yeshasvini $\mathrm{CBHI}$ shows that the overall health expenditures were $19-20 \%$ higher among the insured than the uninsured [25].

In some settings, despite of MHI reducing the overall health expenditures, it may not be able to relieve the poorest segments of the society from financial burden. The impact evaluation study from Benin, included in our paper, indicated that even though the hospitalization expenses were significantly reduced among members of the $\mathrm{MHO}$, the overall benefits of the scheme for the poor were not proven [37].

\section{Poverty}

A research paper, also included in this review, evaluates the effect of Grameen Bank MHI on poverty reduction, in the rural regions of Bangladesh. The indicators used in this survey to gauge poverty included household income, non-income assets, food sufficiency and probability of being above or below the poverty line. The results of the impact assessment showed a positive relation between $\mathrm{MHI}$ and the mentioned indicators, hence proving that MHI plays a role in poverty reduction. However, the results were statistically significant for only food sufficiency [38]. A paper from China studies the role of governmentled NCMS in preventing medical impoverishment among the rural population by doing a comparison between NCMS beneficiaries and beneficiaries of another MHI scheme RMHC. It was found that NCMS reduced poverty headcount by 3.5-3.9 \%. The authors also proved that the RMHC, in contrast, could reduce poverty by $8.3-13.1 \%$ [20].

\section{Consumption patterns and household assets}

A randomized control trial from ILO's micro-innovation facility in Kenya, describes the impact of Wananchi Savings and Credit Cooperative Society, a micro insurance scheme [30]. It was found that enrollment in the MHI component of the scheme, reduced net health expenditures, decreased informal borrowings for medical costs and improved non-food and overall consumption. Also, the households covered with MHI were found to have greater values of assets and savings.

Another study underlined the impact of a communitybased health insurance (CBHI) scheme, named Assurance Maladie à Base Communautaire', on household assets in rural Burkina Faso, Africa, through a randomized community based trial [33]. The results indicated that this CBHI scheme, not only shielded the household assets but also increased them in Nouana Health District.
The per capita household assets increased by $7 \%$ in 2006 and by $16 \%$ in 2007.

A study from India, evaluating the role of the 'Yeshasvini' CBHI scheme, found that the sale of assets for obtaining primary healthcare is $61 \%$ lower for the CBHI beneficiaries belonging to the poorer segment [25].

\section{Household savings}

Three studies were found to highlight the effect of MHI scheme on household savings.

The study on India's CBHI 'Yeshaswini' program, states that the use of household savings to pay for healthcare is up to $74 \%$ less among the insured than the uninsured [25]. The paper researching the effect of Sampoorna Suraksha program in India indicated that a larger percent of the uninsured group (35.3\%) used household savings to pay for healthcare, compared to insured $(32.7 \%)$ and newly insured (24.7 \%) groups. However, this result was insignificant $(\mathrm{p}>0.05)$ [26].

The study from rural China gave results, which were in contrast of the other included studies. This study examines the effect of the New Cooperative Medical Scheme (NCMS) on household savings across income quartiles in rural China. It was found that NCMS has a negative bearing on savings of middle-income participants; the lower-middle income participants deplete their savings rapidly while the higher-middle income save less compared to the non-participants. This scheme has not proven to have any influence on the household savings of the poorest households [20].

\section{Household borrowing}

Two studies, both from India, discuss the effect of MHI on household borrowings as a risk coping strategy. Among the members of the Yeshasvini CBHI scheme in India, the total borrowings were $30-36 \%$ less than the non-enrollees [25]. Whereas among the enrollees of Sampoorna Suraksha program in Karnataka, India it was found that a lower percentage of insured individuals (57.2\%) relied on borrowings compared to the newly insured $(79.5 \%)$ or uninsured individuals $(75.2 \%)(\mathrm{p}<$ 0.05) [26].

The Table 4 provides a summary of findings (SoF), using guidelines from the Cochrane Handbook for Systematic Review of Interventions version 5.1.0 (modified for the purpose of systematic review) [43]. For the outcomes presented in this review, the effect size is non-quantifiable as the majority of studies included, have not presented the findings statistically, but have just observed the overall qualitative effect of the intervention (MHI) on the outcome (measures of financial protection).

The SoF table also illustrates the number of individuals (or the households, where the individuals are not 
mentioned) being covered in the included studies. This gives an overall picture of the most widely studied outcomes of MHI.

We have also commented on the overall quality of evidence accumulated for the various outcomes. The Mirza and Jenkins checklist, (Table 3) has been used to categorize the quality of overall evidence as low, moderate or high, by taking average of the individual quality scores of the included studies (Table 4).

\section{Discussion}

The findings from the systematic review indicate that largely, MHI has had a positive bearing on the financial protection of low-income households in developing countries.

To the best of our knowledge, this study is the first systematic review that broadly examines the role of MHI in providing financial protection in developing countries.

Our review also points out that no impact evaluation has been undertaken for a vast majority of MHI schemes, even though currently more than 100 such schemes are operational in various developing countries like India [44] and Sub Saharan Africa [43]. In Africa alone, over 14 million (about $1.8 \%$ ) people, mostly those working in the informal sector, are covered by an MHI scheme [45].

Furthermore, in many papers, the effect of MHI being considered is other than financial protection, such as change in healthcare utilization, health seeking behavior or healthcare access. Despite this, the available evidence clearly demonstrates that MHI, in several ways, can contribute in provision of financial protection against the cost of healthcare consumption, particularly to lowincome households in developing countries. In this section, we have also deliberated upon the applicability of MHI schemes in Pakistan as an alternative to user fees as a health financing mechanism.

Findings from 11 out of 23 studies included in this review, point towards reduction in OOP expenditure as a direct result of usage of MHI. This finding is in line with the vision of WHO, that has advocated for the implementation of prepaid health financing mechanisms for mitigating the detrimental effects of user fees [46]. OOP spending in Pakistan, as percent of the gross domestic product (GDP) is $55 \%$ [12]. Even when attending the government-funded health care system, a patient is expected to cover various costs like user fees as well as medication, transportation and other consumables [13]. Globally, high OOP spending has been associated with impoverishment or financial catastrophe [47] making it vital to consider a risk pooling mechanism, such as MHI, to cover health financing needs of a country like Pakistan, where $21.04 \%$ of the population live below the poverty line of $\$ 1.25$ per day $[12,48]$.
In this review, we found convincing evidence regarding the positive effect of MHI on risk coping strategies such as the sale of assets, depletion of household savings, decreased consumption patterns and household borrowings. In Pakistan, the coping strategies most often employed by low-income households to address healthcare costs, include drawing down savings, borrowing and selling productive assets such as cattle, poultry and land [14]. These are frequently inadequate to cover the health expenditure and the consequential debt can result in the impoverishment of the effected households [9].

We could find very little evidence on the direct impact of MHI on poverty. Therefore, no conclusion can be drawn in this regard. However the reduction in OOP expenditure, borrowings and sale of assets could all indirectly prevent impoverishment due to health expenditures [9]. In addition to financial protection, MHI schemes have also shown to improve access to and utilization of health care in many developing countries $[48,49]$. The improved health status can lead to higher economic growth [50], which may also, in turn, lead to poverty reduction.

In light of the evidence presented in this review, there is a strong rationale for the wide-ranging implementation of MHI in Pakistan, specifically in areas of the country where supply of health services may not be deficient. However, feasible MHI schemes in developing economies may be arduous to develop and challenging to sustain [51]. The threats to sustainability include high expense ratios, higher probabilities of loss because of poorer health statuses of the insured; inadequate infrastructure; risky living and working environments; and lack of understanding of the insurance mechanism [51]. In these markets, the MHI designs are kept simple due to data limitations, high transaction costs and low levels of education of the people and therefore may suffer from adverse selection [51].

In Pakistan, the insurance industry is still in infancy. In 2005, Pakistan was ranked at 58th position in the global insurance market by volume, with China and India at $9^{\text {th }}$ and $15^{\text {th }}$ positions respectively [52]. In the Asian region, the share of insurance density for Pakistan is $5 \%$ as opposed to $18 \%$ of Sri Lanka, $32 \%$ of China and $43 \%$ of India [53]. Insurance density provides evidence on the expenditure on insurance provision and is calculated as ratio of premiums collected per capita [54]. In 2008, insurance penetration in Pakistan was merely $0.7 \%$ of the GDP [51]. Within this industry, there is a limited share of micro insurance [51]. Only a few MHI schemes have been operational in Pakistan, and none have been subjected to impact evaluation. A qualitative study rolled out in Ghizar district of Pakistan, to study the effect of MHI implemented by the Aga Khan Agency for Microfinance (AKAM) [55] revealed an extremely 
Table 6 MOOSE Checklist

\begin{tabular}{ll} 
Item & Recommendation \\
\hline $\begin{array}{l}\text { Reporting of background should include } \\
1\end{array}$ & Problem definition \\
2 & Hypothesis statement \\
3 & Description of study outcome(s) \\
4 & Type of exposure or intervention used \\
5 & Type of study designs used \\
6 & Study population
\end{tabular}

Reported on Page No

Reporting of search strategy should include

$7 \quad$ Qualifications of searchers (eg, librarians and investigators) 2

8 Search strategy, including time period included in the synthesis and key words 2

9 Effort to include all available studies, including contact with authors 3

10 Databases and registries searched $2-3$

11 Search software used, name and version, including special features used (eg, explosion)

12 Use of hand searching (eg, reference lists of obtained articles)

2

2

2

$2-3$

Not applicable. No search software was used

3

Table 2 (page 5) and Table 5 (page 10-17)

3

3

16 Description of any contact with authors 3

Reporting of methods should include

17 Description of relevance or appropriateness of studies assembled for assessing the hypothesis to be tested 3

18 Rationale for the selection and coding of data (eg, sound clinical principles or convenience)

19 Documentation of how data were classified and coded (eg, multiple raters, blinding and interrater reliability)

20 Assessment of confounding (eg, comparability of cases and controls in studies where appropriate)

3.No coding of data was required

4No coding of data was required

9 (matching of cases and controls done in few included studies)

21 Assessment of study quality, including blinding of quality assessors, stratification or regression on possible predictors of study results

22 Assessment of heterogeneity

4

Not applicable

Not applicable of whether the chosen models account for predictors of study results, dose-response models, or cumulative meta-analysis) in sufficient detail to be replicated

24 Provision of appropriate tables and graphics

Tables given

Reporting of results should include

25 Graphic summarizing individual study estimates and overall estimate

Not applicable

26 Table giving descriptive information for each study included

27 Results of sensitivity testing (eg, subgroup analysis)

28 Indication of statistical uncertainty of findings

Reporting of discussion should include

29 Quantitative assessment of bias (eg, publication bias)

Table 5 (page 10-17)

Not applicable

Not applicable

Not applicable. This is a qualitative systematic review

3 \& 5 (Table 2)

6-8 (Table 3), 22 
Table 6 MOOSE Checklist (Continued)

\begin{tabular}{lll}
\hline Reporting of conclusions should include & 22 \\
32 & Consideration of alternative explanations for observed results & 22 \\
33 & $\begin{array}{l}\text { Generalization of the conclusions (ie, appropriate for the data presented and within the domain of the } \\
\text { literature review) }\end{array}$ & 22 \\
34 & Guidelines for future research & Not applicable
\end{tabular}

From: Stroup DF, Berlin JA, Morton SC, et. al., for the Meta-analysis Of Observational Studies in Epidemiology (MOOSE) Group. Meta-analysis of Observational Studies in Epidemiology. A Proposal for Reporting. JAMA. 2000;283(15):2008-2012. doi: 10.1001/jama.283.15.2008

Transcribed from the original paper within the NEUROSURGERY ${ }^{\oplus}$ Editorial Office, Atlanta, GA, United Sates. August 2012

low first year penetration of $4 \%$, mostly due to cost constraints, lack of awareness about the availability of the product, lack of understanding of the product mechanism or trust in the scheme [55]. The AKAM scheme has also been associated with adverse selection primarily due to lack of individual risk classification [55]. There is a certain need to take steps to counter adverse selection to ensure business feasibility. Secondly, the schemes currently being offered primarily cover catastrophic expenditure, excluding preexisting conditions, outpatient visits, outpatient medication and maternity services because of which the uptake remains low [56]. Offering customized packages to the consumers, after a careful market survey could help improve uptake. Furthermore, marketing remains a crucial strategy to attain good enrollment rates for voluntary insurance schemes such as MHI [55].

The measures of financial protection assessed in this review are suggestive of a likely association between MHI and financial protection. However, while considering the applicability of MHI in Pakistan, the policy makers must be cognizant of the barriers to feasibility of implementation. The findings of this review could be used, with careful consideration of supply side and feasibility issues, in forming the basis for any MHI scheme in the country.

The MOOSE checklist was utilized to report this systematic review, which can be considered a strength of this study (Table 6) [57].

\section{Limitations}

Our review points to a narrow evidence base as only 23 studies could meet our inclusion criteria. The review also revealed a large variation in study design and quality. Only two studies had used experimental study design, while most others used observational analysis to compare various measures of financial protection among insured individuals with those in a control group (perhaps the same individuals but formerly insured, or different individuals without prior insurance). Only one study met all the quality criteria used in this review.

This systematic review emphasizes the potential usefulness of developing guidelines for appropriately measuring the impact of MHI. There is a definite need to conduct studies using more rigorous designs and impact indicators for MHI impact evaluations. It is also imperative to measure its effect on other aspects of coping strategies for health expenditures such as foregone care or decreased economic productivity.

\section{Conclusion}

Micro health insurance, targeted at low-income households in developing countries, has made a considerable contribution in providing financial protection from health care expenditures. The results indicated a positive influence of MHI on OOP, CHE, poverty, health expenditures, household consumption, borrowings, sale of assets and household savings (protective effect).

The findings in this review can be used, with careful deliberation, to guide future policies and MHI programmes in Pakistan. However, the upcoming schemes should be tailored to suit the cultural and sociopolitical environments, specific to various geographical settings in Pakistan. There is also a dire need to conduct more research in this field. With the use of more robust study designs and impact indicators, the emerging evidence will be increasingly significant.

\section{Abbreviations \\ CHE: catastrophic health expenditure; CTP: capacity to pay; FATA: Federally Administered Tribal Areas; GDP: gross domestic product; HCFP: health care fund for the poor; ILO: International Labour Organization; KPK: Khyber Pakhtunkhwa; MHI: micro health insurance; $\mathrm{MHO}$ : mutual health organization; NCMS: new cooperative medical scheme; NHA: National Health Accounts; OOP: out of pocket; URBI: urban resident basic medical insurance; WHO: World Health Organization.}

\section{Competing interests}

The authors declare that they have no competing interests.

\section{Authors' contributions}

The authors involved in this review are health policy graduates with MSc. in Health Policy and Management. SH and SP conceptualized the systematic review and developed the search criteria. SH then conducted the systematic and manual searches. SH and HM were involved in data extraction. HM conducted the quality assessment of the included studies. SH prepared the first draft of the manuscript. SP reviewed the drafts of the manuscript. All three authors approved the final version of the manuscript.

\section{Acknowledgements}

The authors would like to thank Dr. Fauziah Rabbani, Professor and Chair, Department of Community Health Science, The Aga Khan University, Pakistan, 
for her technical assistance in developing literature search criteria and for providing overall guidance during initial planning of this systematic review.

\section{Author details}

'Department of Community Health Sciences, The Aga Khan University, Stadium Road, 74800 Karachi, Pakistan. ${ }^{2}$ School of Nursing \& Midwifery, The Aga Khan University, Stadium Road, 74800 Karachi, Pakistan.

\section{Received: 9 October 2015 Accepted: 8 March 2016} Published online: 22 March 2016

\section{References}

1. Pauly MV, Zweifel P, Scheffler RM, Preker AS, Bassett M. Private health insurance in developing countries. Health Aff. 2006;25(2):369-79.

2. Xu K, Evans DB, Kawabata K, Zeramdini R, Klavus J, Murray CJ. Household catastrophic health expenditure: a multicountry analysis. Lancet. 2003; 362(9378):111-7.

3. Van Doorslaer E, O'Donnell O, Rannan-Eliya RP, Somanathan A, Adhikari SR, Akkazieva B, et al. Paying out-of-pocket for health care in Asia: Catastrophic and poverty impact. Rotterdam and IPS, Colombo: Erasmus University; 2005.

4. Kawabata K, Xu K, Carrin G. Preventing impoverishment through protection against catastrophic health expenditure. Bull World Health Organ. 2002; 80(8):612.

5. Dror DM, Jacquier C. Micro-insurance: Extending Health Insurance to the Excluded. Int Soc Secur Rev. 1999;52(1):71-97.

6. Peters DH, Garg A, Bloom G, Walker DG, Brieger WR, Hafizur Rahman M. Poverty and access to health care in developing countries. Ann N Y Acad Sci. 2008;1136(1):161-71.

7. Iyer A, Sen G, George A. The dynamics of gender and class in access to health care: Evidence from rural Karnataka, India. Int J Health Serv. 2007; 37(3):537-54.

8. Mills A, Ataguba JE, Akazili J, Borghi J, Garshong B, Makawia S, et al. Equity in financing and use of health care in Ghana, South Africa, and Tanzania: implications for paths to universal coverage. Lancet. 2012;380(9837):126-33.

9. Malik AM, Syed SIA. Socio-economic determinants of household out-ofpocket payments on healthcare in Pakistan. Int J Equity Health. 2012;11:51.

10. Dror DM, Soriano ES, Lorenzo ME, Sarol JN, Azcuna RS, Koren R. Field based evidence of enhanced healthcare utilization among persons insured by micro health insurance units in Philippines. Health Policy. 2005;73(3):263-71.

11. Gotsadze G, Bennett S, Ranson K, Gzirishvili D. Health care-seeking behaviour and out-of-pocket payments in Tbilisi, Georgia. Health Policy Plan. 2005;20(4):232-42.

12. National Health Accounts Pakistan 2011-12. In. Edited by Statistics Division GoP. Pakistan: Pakistan Bureau of Statistics; 2014

13. Nishtar S. Choked pipes: reforming Pakistan's mixed health system. Oxford: Oxford University Press; 2010

14. Kruk ME, Goldmann E, Galea S. Borrowing and selling to pay for health care in low-and middle-income countries. Health Aff. 2009;28(4):1056-66.

15. Spaan E, Mathijssen J, Tromp N, McBain F, Have A, Baltussen R. The impact of health insurance in Africa and Asia: a systematic review. Bull World Health Organ. 2012;90(9):685-92.

16. Berkhout $\mathrm{E}$, Oostingh $\mathrm{H}$ : Health Insurance in Low Income Countries: Where is the evidence that it works? 2008 [Epub ahead of print].

17. Carrin G, Waelkens MP, Criel B. Community-based health insurance in developing countries: a study of its contribution to the performance of health financing systems. Tropical Med Int Health. 2005;10(8):799-811.

18. Churchill CD: What is insurance for the poor? In: Protecting the poor: A microinsurance compendium. Volume 11, edn.: International Labour Organization (ILO) in association with GSE Research; 2006: 11-24.

19. Mirza I, Jenkins R. Risk factors, prevalence, and treatment of anxiety and depressive disorders in Pakistan: systematic review. BMJ. 2004;328(7443):794.

20. Yip W, Hsiao WC. Non-evidence-based policy: how effective is China's new cooperative medical scheme in reducing medical impoverishment? Soc Sci Med. 2009;68(2):201-9.

21. Hou Z, Van de Poel E, Van Doorslaer E, Yu B, Meng Q. Effects of NCMS on access to care and financial protection in China. Health Econ. 2014:23(8):917-34.

22. Qiang S, Xiaoyun L, Qingyue $M$, Shenglan T, Baorong $Y$, Tolhurst R. Evaluating the financial protection of patients with chronic disease by health insurance in rural China. Int J Equity Health. 2009:8:42.

23. Cheung D, Padieu Y. Heterogeneity of the effects of health insurance on household savings: Evidence from rural China. World Dev. 2015;66:84-103.
24. Wagstaff A, Lindelow M, Jun G, Ling X, Juncheng Q. Extending health insurance to the rural population: An impact evaluation of China's new cooperative medical scheme. J Health Econ. 2009;28(1):1-19.

25. Aggarwal A. Impact evaluation of India's 'Yeshasvini'community-based health insurance programme. Health Econ. 2010;19(S1):5-35.

26. Savitha B, KB K. Microhealth insurance and the risk coping strategies for the management of illness in Karnataka: a case study. Int J Health Plann Manag. 2013;30:145.

27. Devadasan N, Criel B, Van Damme W, Ranson K, Van der Stuyft P. Indian community health insurance schemes provide partial protection against catastrophic health expenditure. BMC Health Serv Res. 2007;7(1):43.

28. Saksena P, Antunes AF, Xu K, Musango L, Carrin G. Mutual health insurance in Rwanda: evidence on access to care and financial risk protection. Health Policy. 2011;99(3):203-9.

29. Lu C, Chin B, Lewandowski JL, Basinga P, Hirschhorn LR, Hill K, et al. Towards universal health coverage: an evaluation of Rwanda Mutuelles in its first eight years. PLoS One. 2012;7(6):e39282.

30. Dercon S, Gunning JW, Zeitlin A, Lombardini S: The impact of a health insurance programme: Evidence from a randomized controlled trial in Kenya. Research Paper. 2012(24)

31. Kihaule A: Impact of Micro Health Insurance Plans on Protecting Households Against Catastrophic Health Spending in Tanzania. GSTF J Nurs Health Care (JNHC) 2015; 2(2):71-77.

32. Dekker M, Wilms A. Health Insurance and Other Risk-Coping Strategies in Uganda: The Case of Microcare Insurance Ltd. World Dev. 2010;38(3):369-78.

33. Parmar D, Reinhold S, Souares A, Savadogo G, Sauerborn R. Does Community-Based Health Insurance Protect Household Assets? Evidence from Rural Africa. Health Serv Res. 2012;47(2):819-39.

34. Chankova S, Sulzbach S, Diop F. Impact of mutual health organizations: evidence from West Africa. Health Policy Plan. 2008;23(4):264-76.

35. Bodhisane S, Pongpanich S: The Impact of Community Based Health Insurance in Enhancing Better Accessibility and Lowering the Chance of Having Financial Catastrophe Due to Health Service Utilization A Case Study of Savannakhet Province, Laos. International Journal of Health Services 2015: 0020731415595609 [Epub ahead of print]

36. Alkenbrack S, Lindelow M. The Impact of Community-Based Health Insurance on Utilization and Out-of-Pocket Expenditures in Lao People's Democratic Republic. Health Econ. 2013;24:379.

37. Haddad S, Ridde V, Yacoubou I, Mák G, Gbetié M. An evaluation of the outcomes of mutual health organizations in Benin. PLoS One. 2012;7:e47136.

38. Hamid SA, Roberts J, Mosley P. Can micro health insurance reduce poverty? Evidence from Bangladesh. J Risk Insur. 2011;78(1):57-82.

39. Wagstaff A: Health insurance for the poor: initial impacts of Vietnam's health care fund for the poor. In: Impact Evaluation Series. Washington, D.C.; 2007: 1-33.

40. Wagstaff A. Estimating health insurance impacts under unobserved heterogeneity: the case of Vietnam's health care fund for the poor. Health Econ. 2010;19(2):189-208.

41. Pham TT, Pham TL: Does Microinsurance help the poor? Evidence from the targeted health insurance program in Vietnam 2004-2008. Research Paper 2012(11).

42. Franco LM, Diop FP, Burgert CR, Kelley AG, Makinen M, Simpara CHT. Effects of mutual health organizations on use of priority health-care services in urban and rural Mali: a case-control study. Bull World Health Organ. 2008;86(11):830-8

43. Schünemann HJ, Oxman AD, Higgins JP, Vist GE, Glasziou P, Guyatt GH: Presenting results and 'Summary of findings' tables. Cochrane Handbook for Systematic Reviews of Interventions In Version 2008; 5(02).

44. Kiran D. Micro health insurance: An overview of Indian scenario. J Ayurveda Holist Med (JAHM). 2013;1(9):23-8.

45. Leppert G, Ouedraogo L-M: Handbook of Micro Health Insurance in Africa. In. Volume 1, edn.: LIT Verlag Münster; 2012: 48-59.

46. The World Health Report 2000: Health Systems: Improving Performance. In.: World Health Organization; 2000: 111-140.

47. Nishtar S, Khalid F, Ikram A, Javad A, Jaffer H, Brown K, Badsha T: Protecting the poor against health impoverishment in Pakistan: Proof of concept of the potential within innovative web and mobile phone technologies. World health report. 2010;55

48. ul Huda S. Determinants of population growth in Pakistan. Int J Endorsing Health Sci Res. 2014;2(2):97-9. 
49. Jütting JP. Do community-based health insurance schemes improve poor people's access to health care? Evidence from rural Senegal. World Dev. 2004;32(2):273-88.

50. Bloom DE, Canning D, Sevilla J: The effect of health on economic growth: a production function approach. World Development. 2004;32(1):1-13.

51. Yao YK: Sustainability and Adverse Selection in Emerging Health Insurance Markets: Evidence from Microinsurance in Pakistan. United States: The University of Wisconsin-Madison; 2012.

52. Akhter W, Zia-ur-Rehman M. Financial Performance of Pakistan Insurance Industry in Global Scenario. Far East J Psychol Bus. 2011;3(1):1-14.

53. Rodrik D. Saving transitions. World Bank Econ Rev. 2000;14(3):481-507.

54. Micro-insurance: Demand and Market Prospects-India. In: Public Private Partnership. Allianz AG, GTZ and the United Nations Development Programme (UNDP); 2006.

55. McGuinness E, Mandel J: Assessment of Health Microinsurance Outcomes in the Northern Areas, Pakistan - Baseline Report. In. United States: IRIS and Microfinance Opportunities; 2010

56. Chaudhry TT, Nabeel F: Microinsurance in Pakistan: Progress, Problems, and Prospects. The Lahore Journal of Economics. 2013;(18):335-374.

57. Stroup DF, Berlin JA, Morton SC, Olkin I, Williamson GD, Rennie D, Moher D, Becker BJ, Sipe TA, Thacker SB. Meta-analysis of observational studies in epidemiology: a proposal for reporting. Jama. 2000;283(15):2008-12.

\section{Submit your next manuscript to BioMed Central} and we will help you at every step:

- We accept pre-submission inquiries

- Our selector tool helps you to find the most relevant journal

- We provide round the clock customer support

- Convenient online submission

- Thorough peer review

- Inclusion in PubMed and all major indexing services

- Maximum visibility for your research

Submit your manuscript at www.biomedcentral.com/submit 